\title{
A estrangeiridade em Os sertões e o dilema da alteridade na imprensa brasileira
}

\author{
[ Foreignness in "Rebellion in the backlands" and the \\ dilemma of otherness in the Brazilian press
}

\section{Otávio Ávila}

RESUMO - $O$ artigo tem por objetivo refletir sobre o estatuto da estrangeiridade do sertanejo na obra máxima de Euclides da Cunha. Utilizando conceitos de teóricos das migrações, discute-se a contribuição que a obra dá ao tema a partir das próprias contradições existentes nela sobre a alteridade, a pureza e a nacionalidade construídas a partir do pensamento positivista que dominava os intelectuais desse período e refletia nas formas midiáticas da imprensa. Ao fim, é feita uma reflexão dos rumos da "grande imprensa" nos dias de hoje e as novas formas de representação popular. PALAVRASCHAVE - Estrangeiro; alteridade; imprensa. .

\begin{abstract}
The article aims to reflect about the foreignness statute of the backwoodsman in the Euclides da Cunha masterpiece. Using migrations theoretical concepts, it discusses the contribution that this book report gives for the migration's theme from their own existing contractions about otherness, purity and nationality constructed from positivist thought that dominated the intellectuals of this period and reflected of media forms of the press. By the end, the texte reflects about the mainstream press in nowadays and its forms of popular representation. - KEYWORDS . Stranger; otherness; press.
\end{abstract}

Recebido em I8 de junho de 2020 Aprovado em 3 I de maio de $202 I$

ÁVILA, Otávio. A estrangeiridade em Os sertões e o dilema da alteridade na imprensa brasileira. Revista do Instituto de Estudos Brasileiros, Brasil, n. 79, p. 36-52, ago. 202I.

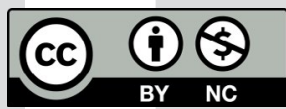

DOI: https://doi.org/Io.II6o6/issn.23I6-90IX.vIi79p36-52

I Universidade Federal do Rio de Janeiro (UFRJ, Rio de Janeiro, RJ, Brasil). 


\section{INTRODUÇÃo (OBJETIVOS DE UM NOVO ESTUDO)}

O crítico literário Antonio Candido afirmou certa vez não haver na literatura nacional uma obra que desse conta de desenhar a imigração ${ }^{2}$ no país nos moldes dos explicadores da vida brasileira que escreveram sobre a formação e o ordenamento da nossa diversidade social. Com o passar dos anos, o desenvolvimento das pesquisas em ciências sociais fracionou a produção de conhecimento em especificidades profundamente detalhadas, acionadas para garantir o caráter inovador das produções acadêmicas. Embora a imigração não tenha sido tratada de forma ampla, como ressaltou Candido, ela, a imigração, apresentou-se nessas especificidades típicas de sua amplitude como "fato social total" (SAYAD, I998).

Em um valoroso artigo, Chiarelli (20I6) evoca na literatura traços ainda específicos do universo migratório ligados a cada uma das nacionalidades, como a chegada italiana ao país no relato personalizado de Zélia Gatai em Anarquistas, graças a Deus, publicado em I979; a ficção em primeira pessoa de Milton Hatoum, Relato de um certo Oriente, de I989, em que descreve elementos particulares do trânsito entre o Brasil e o Líbano; e, a título de mais um exemplo, dentre tantos elencados por ela, a narração da imigração judaica (de russos) por Moacyr Scliar, A majestade do Xingu, de I997, livro no qual o autor une a literatura a outra especialidade particular: a medicina.

No âmbito da pesquisa, importantes contributos foram dados pela antropóloga Giralda Seyferth sobre o aspecto cultural da imigração com enfoque nos processos de racismo e preconceito no Sul do país; Bela Feldman-Bianco acumula publicações sobre migrações e deslocamento e apresenta importantes reflexões sobre a saudade; Octavio Ianni, sociólogo crítico da globalização, debruçou-se também sobre o preconceito racial e empreendeu pesquisas sobre a migração no Sul do Brasil coordenadas por Florestan Fernandes. Apenas alguns nomes no labirinto temático no qual estava imerso Candido em sua crítica. Com tantas nuances e demasiadamente europeizado, o estudo das migrações no Brasil por vezes esteve vinculado a um aprofundamento

2 Utilizo os termos migração, imigração e emigração. É um uso consciente para demarcar diferenças contextuais. 
identitário da Região Sul, como fez Wilson Martins em Um Brasil diferente, de I955, livro no qual o crítico literário reavalia a "nacionalidade" da Casa-grande ersenzala limitando-o a uma faceta de um Brasil diferente daquele erigido no estado do Paraná. No entanto, a atualidade abrange os estudos migratórios para além da chegada dos europeus ao país entre I880 e I940. Cabem os novos trânsitos entre os países do eixo do sul global potencializados a partir das décadas de I970 e I980, as dinâmicas de refúgio do século XXI e a proeminência na pesquisa científica, sobre o que a literatura também se debruça: os aspectos subjetivos do deslocamento humano no indivíduo e nas sociedades.

Voltando ao início do século XX, na linha tênue entre a literatura e as ciências sociais, Os sertões: Campanha de Canudos aparece nesse entrelugar como obra ímpar escrita nos moldes da tríade analítica entre o meio, a raça e o momento, preconizada pelo positivista francês Hippolyte Taine. A tríade situa a obra no conjunto de empreendimentos intelectuais cientificistas do século XIX que carrega como marca indelével a construção interpretativa de um jornalista contratado para cobrir a última expedição das forças republicanas contra os rebeldes de Canudos na virada para o século XX. Entre literatura, ciência e reportagem, o livro, publicado em I902, ainda abre espaço para diversas e sempre providenciais interpretações do Brasil.

No entanto, a obra de Euclides da Cunha não trata da imigração. Por que, então, analisá-la nessas referências? A resposta está no caráter de estrangeiridade entre os pretensos civilizados e os sertanejos. É essa, justamente, a característica demarcadora na relação entre o imigrante e a cultura receptora. Desde Georg Simmel e Alfred Schütz, é o fato de ser estranho junto a ela que o torna estrangeiro, independente da fronteira entre os Estados-nação que organiza a política das migrações. Euclides ${ }^{3}$ reforça a principal distância com o "outro", que, do paradigma oceânico, ou seja, das diferenças culturais pelas diferentes formas de compartilhamento de significados com outros continentes, vai para a distância temporal encontrada entre o homem litorâneo e o sertanejo, separados por séculos, segundo suas reflexões (CUNHA, 20I2, p. I58). Vale a pena lembrar que o mote da obra se completa na dúvida sobre o estatuto civilizatório quando o desfecho da quarta expedição a Canudos se concretiza no massacre do arraial baiano. Imbuído da crença no progresso e na ciência que marcou o pensamento positivista desses intelectuais, o autor passa por aquilo que Homi Bhabha (2013) entende como um espaço a que a cultura está submetida: um entrelugar deslizante que desestabiliza os essencialismos pelo confronto entre sistemas culturais diferentes. Quem seria, de fato, o civilizado? Quem seria o estrangeiro quando o encontro com as diferenças já não é possível ser suspenso?

$\mathrm{O}$ artigo também não esquece d'Os sertões como redação jornalística, afinal, no Brasil, a arte de informar esteve a cargo dos homens das letras antes do jornalismo se tornar uma área específica de conhecimento (SODRÉ, I999). Tendo sido Euclides enviado a Canudos como correspondente do jornal $O$ Estado de S. Paulo, abro espaço à reflexão da produção de uma imprensa elitizada. É ela também que marca no tecido social o estatuto da diferença, da estranheza e do estereótipo para as minorias sociais, nesse caso, os sertanejos; hoje, todos aqueles que estão à margem, desestabilizando a

3 Utilizarei o primeiro nome do autor ao invés do sobrenome, contrariando o costume dos artigos acadêmicos. A justificativa para isso é a força do seu primeiro nome em detrimento do segundo na literatura brasileira. 
cultura. São essas as contribuições oferecidas para uma obra inesgotável e que serve à inconclusa formação (pluri)cultural brasileira.

\section{A República, o escritor e o Brasil (InTROdução À Obra, O JORnAlista EUCLIDES da CUNHA)}

A influência de Taine no pensamento científico do final do século XIX está exposta na divisão de Os sertões. A terra, o homem e a luta são os capítulos iniciais que estruturam o texto e são, na tradução euclidiana, respectivamente, o meio, a raça e o momento. A formulação dessa corrente de pensamento se baseia na associação da raça com o ambiente no qual ela está inserida e pelo qual ela é determinada. As raças seriam explicadas a partir das condições que o meio ambiente disponibiliza para a sobrevivência e pelas relações sociais que se utilizam do darwinismo biológico (de matriz reprodutiva por uma herança seletiva das características mais adaptadas à sobrevivência da espécie) como explicação inicial, mas que se amparam em um tecido social (chamado equivocadamente de "darwinismo social”) não pensado por Charles Darwin em A origem das espécies (I859). Tratava-se, pois, de uma luta direta entre raças e classes, interpretada em termos biológicos e que balizaria a sobrevivência pela competição, característica do liberalismo proposto por Herbert Spencer.

Essas são marcas contextuais que povoam a formação intelectual de Euclides da Cunha. Sua biografia foi extensamente debatida e publicada, no entanto, é imperioso o ordenamento de algumas premissas para o entendimento de como ele constrói o sertanejo pela diferença imposta "por três séculos" de distância cultural com o mundo de um engenheiro militar e todas as teorias científicas surgidas na virada do século e que faziam eco à sua classe.

Não que a dicotomia entre o "civilizado" e o sertanejo fosse absoluta. Sevcenko (I989) coloca Euclides na esteira de seu tempo, entre um século XIX literário, romântico e idealista, e um século XX científico, naturalista e materialista. Mundos negando um ao outro, mas coexistindo no escritor, fazendo-o resistir aos traços da modernidade que acompanhavam, na vida cultural, a doutrina de progresso da vida social e econômica.

Marcado por um lirismo romântico da juventude explicitado por Oliveira (2002), Euclides ainda reconhece o sertão como lugar de fundação da nação. Seu prosaísmo está marcado por seus viventes, sertanejos derivados da miscigenação entre o indígena e o bandeirante, que não são, contudo, os cidadãos da nação republicana pela qual ele reza. Logo voltaremos ao ponto do sertão e seus indivíduos. Atemo-nos ao pensamento do autor para pensarmos na genealogia do "outro" construída por ele.

Seguindo aqui a tríade de Taine, embora eu não entenda como ideal tal determinismo, o indivíduo se encontra em um meio marcado pelos ideais cientificistas que nortearam intelectuais, como já dito, e envolto na redoma militar da então capital nacional que acompanha a revolução burguesa europeia incidida no Brasil pelos ideais de progresso. Como bem transitou Gilberto Freyre, da casa-grande e senzala para os sobrados e mocambos, a vida social rural deu lugar à vida nas cidades e com ela a valorização do conhecimento em detrimento das hierarquias imperiais-religiosas. $\mathrm{O}$ patriarca da casa-grande não desempenha mais poder absoluto nos 
sobrados, locais nos quais, segundo Jessé Souza (20I9), entram os médicos familiares como exemplo das novas fronteiras de um poder ligado aos saberes modernos, onde antes a força do patriarca cedia espaço apenas ao confessor religioso.

Emerge uma nova ordem imbuída dos valores republicanos oriundos da Europa burguesa e industrial (franco-bretã, não ibérica). Aqui também entrará o imigrante do Velho Continente, sinal do anseio por um novo Brasil mais branco e "civilizado". A importante pintura de Modesto Brocos, A redenção de Cam, datada de I895, mostra três gerações de uma família. A mais velha e mais negra roga a Deus pela mais jovem, que se encontra no meio da tela; alva, resultado de uma mestiçagem embranquecida, é espelho da esperança racialista que alimentava idealistas nos últimos suspiros de uma escravidão já não desejada pelos homens da cidade e ainda contrariada pelos homens da casa-grande, cujo oligopólio escravista perdia força pela chegada das máquinas. Reforça Souza (2019, p. 72):

Quando a modernidade europeia chega ao Brasil de navio, na esteira da troca de mercadorias, seus valores não são uma mera mercadoria de consumo. Afinal, seriam esses valores que iriam presidir a institucionalização incipiente de formas extremamente eficazes de condução da vida cotidiana: o Estado e o mercado capitalista.

Mas, para chegar à modernidade desejada, seria preciso parar em uma estação-chave, chamada unidade nacional. Consolidar a nação era fundamental aos desejos civilizacionais. $\mathrm{O}$ discurso totalizante dos Estados-nação parece ser mais bem-aceito no Brasil, visto que países com processos de unificação longos e pesarosos, como a Itália e a Alemanha, primeiro enfrentaram a histórica separação cultural, política e social dos seus territórios para aí contraírem símbolos nacionais que os unificassem. Ou seja, primeiro povo, depois nação, ainda que as assimetrias socioculturais sejam evidentes por onde fronteiras foram (quase sempre) forçosamente traçadas. No Brasil, o processo foi inverso, porém não menos problemático. Primeiro constituído como nação para depois se pensar em povo. As novas configurações demográficas se formaram ao redor do índio, do português e do negro concomitantemente ao estatuto de "Brasil" (como conceito) que surgia a galope - de insurreições, chacinas e escravidão, menos necessariamente nessa ordem e mais como acontecimentos paralelos. A formação forçada de um povo e de uma nação é o saldo dos empreendimentos colonialistas ibéricos iniciados ainda no século XV, com a descoberta do continente americano e o uso dos territórios interatlânticos como anexo nacional, e da continuidade sociocultural da colonialidade como esperança civilizacional. De igual forma e a partir da ocupação majoritariamente litorânea do Brasil (primeiramente protetora e só depois exploratória), o economista Carlos Brandão argumenta sobre as defasagens habitacionais de um país de dimensões continentais:

Nesse contexto histórico peculiar, o país será “cicatrizado" pelas especificidades históricas de ter construído instituições de âmbito nacional com enormes descontinuidades, defasagens, contradições e hiatos temporais; de ter demarcado um território nacional, depois "arrumado" população para esse imenso espaço; em seguida, de ter erigido um Estado nacional [...]. (BRANDÃO, 20I2, p. 90). 
O ponto de vista econômico de Brandão associa o alto custo da ocupação do território ao fato de as elites precisarem chegar aos espaços mais distantes das camadas litorâneas do país. Um desses elementos foi o ciclo do ouro, força mercantil resguardada ao século XVIII pela descoberta de uma riqueza natural inexplorada. Trazendo o fator explicativo econômico da concentração de renda e populacional no mapa brasileiro, mesmo não sendo foco deste artigo, é que podemos compreender que o desígnio de progresso motivado pelas elites produz uma brasilidade voltada ao espaço de civilidade e progresso, típica do lugar onde se encontra Euclides. Oposto, afinal, ao lugar de Canudos e seus sertanejos. Estrangeiros e nativos do mesmo território.

Antes de evocar o debate sobre a estrangeiridade no capítulo seguinte, é preciso ressaltar que a relação de diferença entre os litorâneos e os sertanejos se deu numa discrepância econômica que reverbera o embate civilizacional encontrado na chegada da República. Caio Prado Júnior (20II, p. 36) relata que o povoamento no Brasil colonial se expandiu ao interior com viés econômico a partir do "bandeirismo preador de índios e prospector de metais e pedras preciosas". O sertão baiano e pernambucano é lembrado pelos rebanhos bovinos, pelo pasto que abasteceria o consumo de carne onde a agricultura era inviável. Embora marcado pelos chapadões no relevo, o clima hostil do sertão não era favorável à criação do gado. A cultura pecuária sertaneja sobrevive economicamente mais pela proximidade ao centro litorâneo e pela falta de concorrência, fator que é subvertido já ao fim do século XVIII pelo charque rio-grandense que desbanca a região. Mas o povoamento nordestino já estava concretizado, amparado pelas margens do São Francisco, do Rio Parnaíba e seus afluentes.

Entendendo o meio e o indivíduo, é possível também estabelecer um paralelo com Taine pelo momento vivido por Euclides da Cunha. Não se tratava apenas de uma guerra sobre a qual ele deveria cobrir como enviado da imprensa paulista. Tratava-se, na opinião dos republicanos do eixo Rio-São Paulo, da luta contra a barbárie notabilizada pelo atraso de selvagens que, de tão atemporizados, não percebiam que o trem da história passava pelo país substituindo a monarquia pelos valores republicanos. Como militar, entendia como necessária a coibição dos adeptos de Antônio Conselheiro insuflados pelo carisma do líder messiânico. A mentalidade dos armados pensava nas estratégias de prolongamento espacial daquilo que até então era movido por um povoado despossuído, mas que apresentava precedentes como a Inconfidência Mineira, de natureza separatista contra a Coroa portuguesa no fim do século XVIII; a Revolta dos Malês, de homens escravizados de maioria muçulmana na capital do mesmo estado da Bahia, em I835; como também posteriormente, na década seguinte, viria acontecer a Guerra do Contestado, agora no Sul do Brasil, também marcada pela revolta contra o poder federal e certo messianismo.

\section{ESTRANGEIROS, NÃO IMIGRANTES (DISCUSSÃO SOBRE ALTERIDADE)}

O estudo do estrangeiro e da migração vincula-se à relação de uma sociedade que acolhe um "outro". Esse "outro" ganha aspas porque não atua como uma expressão convencional utilizada na língua, ele é propriamente aquele que estabelece a 
interculturalidade em um ambiente modificado culturalmente. A expressão pode ser alocada no tema das migrações, porém pertence a um universo mais amplo no que diz respeito à alteridade pensada por Ludwig Feuerbach e o reconhecimento da existência de um outro ser diferente e complementar ao Eu. Esse hífen do Eu-Tu (sendo o Tu o que é externo ao Eu, ou seja, a gênese do "outro") é o que dá sentido à vida do homem, à sua existência e verdade, afirmarão Martin Buber e, recentemente, Muniz Sodré (20I4), ao estabelecer tal relação vinculativa como a essência comunicacional. Retomando a linguagem, pela perspectiva de Gilles Deleuze (I974), a expressão pertenceria ao quarto elemento da linguagem, o sentido, produzido na intersecção entre o acontecimento (migração) e a intenção (a interpretação do acontecimento migratório). O “outro”, afinal, seria para Sodré aquilo que não é próprio, mas indissociável à formação do comum que aloca a experiência humana.

Ao compreender epistemologicamente o recurso linguístico para chegar, agora, a uma abordagem mais sociológica, a teoria das migrações e da estrangeiridade apresenta uma perspectiva "virulenta" de uma espécie de contágio externo, ignorando conscientemente que mesmo na relação intracultural há diferenças que podem colocar em xeque a pretensa homogeneidade e coesão grupal. Ou seja, a teoria construtivista avalia que, mesmo nas formas dialógicas entre membros de uma mesma cultura, que dividem formas similares de codificação e decodificação discursivas, o compartilhamento de significados se transforma à medida que as relações humanas se estabelecem. Cultura e homem se transformam de igual forma e, de antemão e seguindo Schröder (2008), toda relação intracultural pode se tornar intercultural a partir de percepções diferentes de realidade.

Por que até os teóricos construtivistas e críticos da concepção estática e objetiva da cultura entendem as migrações como um desafio das sociedades se todo corpo social, em contato ou não com elementos externos, seria movimentado pelos conflitos existentes nas práticas de produção e reprodução de sentidos que cravam nossa existência? Foi pelo empoderamento dos Estados-nação como força da globalização e da modernidade europeia (lembremo-nos da "estação" da unidade nacional, dita anteriormente, a qual o positivismo cientificista brasileiro precisava parar) que se aperfeiçoou nos regimes de poder a figura da nacionalidade e das fronteiras como recorte sociocultural, estabelecendo o que estaria dentro da cultura e, por isso, familiarizada ao campo dos sentidos, e o que estaria fora da cultura, pertencendo ao universo do exótico ou do sonho.

Entre esses dois universos referentes ao externo à cultura é possível verificar a impregnação do efeito colonialista na sociedade moderna. Ao exótico, podemos lembrar das investigações antropológicas que descreveram as culturas ao redor do mundo. Ao passo que os pesquisadores romperam com o mito de um estímulo-resposta que desconsidera o meio e o contexto e marca o objetivismo científico, ainda tínhamos a interpretação do tipo ideal do pesquisador: europeu, homem, branco. Essa crítica é trazida por Favret-Saada (2005), questionando a neutralidade da pesquisa observada e analisada sob o mesmo prisma hegemônico. Já no campo do sonho, Abdelmalek Sayad (I998) lembra dos argelinos que buscaram na França sua realização de vida. O lugar da colonização, desconhecido e inexplorado, cinde-se ao progresso de vida, logo rompido no ato da chegada. Do lugar do sonho, passa a ser o da desilusão, cuja 
melancolia narrada pelos entrevistados o fazem essencializar o imigrante como um trabalhador. Trabalho como meio e fim da imigração. Longe de perfumá-lo à sociedade de mercado ou diminuir o bravo ato do deslocamento, Sayad permite-se reduzir a subjetividade do migrante - que continua a ser o emigrante na África - ao mundo do trabalho. Já não vivente, mas sobrevivente em seu permanente estado de exílio mental, chamado por ele de ghorba.

No universo do exótico ou do sonho, a diferença cultural apresenta como recorte transversal a colonialidade. Esse é também o traço notado em Os sertões, quando o sertanejo é apresentado como o bom selvagem rousseauniano. Embora Euclides carregue consigo o traço romântico do século XIX, como já dito anteriormente, subsiste nele a modernidade ampliada pela influência positivista.

E o traço da colonialidade se exercia na exacerbação do tipo brasileiro, ao mesmo tempo que o condenava. Se o sertanejo era o incivilizado, era também um tipo embrionário do brasileiro, esquecido pela degradação social do homem litorâneo motivada pelo avanço e pelo progresso. Oliveira (2002) fala desse "Brasil profundo" como se Euclides da Cunha transformasse o sertão numa forma mitológica. "No sertão o tempo corre de outra forma, com outro ritmo e dimensão. É um tempo imobilizado, o tempo das origens cosmogônicas e imemoriais da nação" (OLIVEIRA, 2002, p. 525).

No entanto, há que se antever a relação entre estereótipo e tipo como forma de representação, proposta por Richard Dyer (I977) no ensaio Stereotyping e explicada por Stuart Hall em Cultura e representação (20I6). Dyer explica que a tipificação é a forma pela qual entendemos o mundo, classificando pessoas e objetos. Uma mesa é um plano sustentado por pés que o suspendem do chão. As mesas variam, mas há elementos comuns que as caracterizam como tais, tornando a tipificação fundamental à construção de sentidos. Por outro lado, o estereótipo reduz, fixa e naturaliza características particulares de um grupo geral, cindindo o aceitável/normal do inaceitável/anormal. Os tipos sociais estão inseridos na sociedade, os estereótipos não. São abjetos do convívio social justamente porque a estereotipagem atua em lugares de desigualdade de poder que, segundo Hall (20I6), aplicam as normas de uma cultura sobre outra. Assim, o "Eu-Tu” de Feuerbach, Buber e Sodré se produziria inserido em uma hierarquia violenta, de poder e exclusão. Hall explica que essa hierarquia de violência acontece no campo discursivo, aprofundado por Edward Said (I978) ao argumentar sobre o "orientalismo" como uma produção da cultura europeia administradora e produtora de um Oriente desejado. Hall (20I6, p. I96) ainda afirma: "O poder inclui o dominador e o dominado em seus circuitos”, dificultando, para Bhabha (I986), o processo de subjetificação de quem se encontra no interior de um regime de dominação, caso do orientalismo, mas também dos argelinos que emigram para a França, e o inverso da dominação, vivido pelos republicanos no estigma aos homens do sertão.

É pensando nesse estatuto do "outro" pela ótica da diferença, do poder e da representação que podemos afirmar, então, que o sertanejo retratado por Euclides da Cunha é um estrangeiro, não um migrante. Enquanto o migrante é o que se põe em movimento rumo ao desconhecido e lá estremece a ordem estabelecida, o estrangeiro pertence a outra dimensão, mais ampla. Ele é o estranho na cultura hegemônica. O jagunço, o tabaréu, o caipira, o jeca. O estrangeiro, afinal, pode abarcar o imigrante, mas também todo aquele que atua como um "outro" nos padrões culturais 
prevalecentes. A estrangeiridade é marcada pelas migrações, mas diz respeito à ruptura de fronteiras existenciais estimuladas por distanciamentos de toda ordem. É notório o exemplo do texto de Georg Simmel (I950), O estrangeiro, intitulado primeiramente em inglês como The stranger. Simmel poderia ter utilizado "The foreigner", mas preferiu "stranger". A palavra carrega a ambiguidade de quem vem de outro país, mas também de outra cultura e, por isso, um "estranho" para a comunidade receptora. No texto, Simmel (I950) não especifica a dimensão geográfica do estrangeiro porque o enfoque é cultural.

Para o sociólogo precursor da sociologia urbana, o estrangeiro é analisado à luz da formação da cidade e seus relacionamentos. $O$ estrangeiro é aquele que chega depois da sua formação (cabe aqui questionar quando se finalizaria tal processo, podendo-se responder que nunca cessa), e seu atraso na ocupação da civita acarretará diferentes condições no convívio social que também o beneficiam em alguns aspectos, como o papel de mediador de conflitos, "direito" adquirido pela neutralidade atribuída como membro externo de um grupo. Em Simmel, o estrangeiro é a tipificação desse indivíduo que perde sua humanidade em prol da sua condição, convertendo-se em estereótipo de estranheza aos demais. O mesmo diz Schütz (20I0), cujo obra tem o mesmo título da de Simmel, para quem o estrangeiro é um indivíduo sem história perante o grupo receptor. Não à toa, na literatura, o estrangeiro carrega consigo um mistério daqueles que ocultam o seu passado, o qual é, para Schütz, reflexo do que interessa ao grupo receptor. De fato, não é o estrangeiro quem omite, mas os outros que se abstêm de perguntar.

Embora esses autores não tratem abertamente da "inferioridade" civilizacional do estrangeiro, Nedim Karakayali (2006) lembra que a relação entre o estrangeiro e a "sujeira" está presente na história e, no século XX, ela se equipou do aspecto da pobreza para se reafirmar. Lembrar do universo do trabalho e de Sayad (I998) ratifica que o "serviço sujo" da cidade está a cabo do estrangeiro - aqui, o estrangeiro já é o imigrante, notadamente proveniente do terceiro mundo. Sauad entrevistou argelinos imigrados na França, como um homem varredor que sonhou com o destino migrante, deparou-se com o desemprego, "subexistiu" nas minas de carvão e, à época da entrevista, tinha a vassoura como sua melhor amiga. Outro que trata da impureza do estrangeiro éZigmunt Bauman (I998). O sociólogo polonês explica que, na sociedade atual, a impureza é vista como aquilo que invade a ordem e, consequentemente, ganha conotação de perigo quando as forças de poder entendem que ela pode constituir uma nova ordem social. É o que se tem visto, atualmente, no crescimento de governos de "extrema-direita" baseados no fechamento de fronteiras que, mais a fundo, são encerramentos da presença do "outro" na cultura. Ademais, Bauman não enxerga o estrangeiro de forma tão concreta como Simmel ou Schütz, pois na pós-modernidade, como ele chama o período presente, as fronteiras são mais turvas, líquidas, assim como o estatuto de quem seria o estrangeiro.

Embora não pertença ao universo das teorias de migração, como toda essa bibliografia apresentada no capítulo, Os sertões acampa no referido universo quando o estrangeiro analisado não está fora das fronteiras brasileiras, mas fora do Brasil ideal e hegemonizado pelo establishment republicano. A inferioridade e a impureza estão presentes quando a narrativa principal do livro, a expedição do exército federal contra os rebeldes de Canudos, trata-os como uma ameaça a ser combatida. Essa é a síntese da batalha motivada pelo espírito republicano e contra o retrocesso monárquico, mas que também era contra um Brasil “atrasado" e incivilizado. 
Adiante, seguiremos nessa construção da alteridade e analisaremos as controvérsias no texto de Euclides da Cunha. Antes ainda de falarmos da imprensa, faremos um breve mapeamento do livro como fonte discursiva dos usos do "estrangeiro".

\section{Jagunços, tabaréus, brasileiros? Controvérsias sobre a alteridade de Euclides}

Licia Sousa (2008) produziu um instigante artigo para um dossiê sobre a língua portuguesa na imprensa brasileira e utilizou Os sertões como referência de análise. No texto, ela estabelece o distanciamento produzido entre os litorâneos e os sertanejos e busca os adjetivos utilizados por Euclides da Cunha aos homens do interior. De acordo com a autora, jagunços e tabaréus são expressões escolhidas por Euclides ao direcionar sua crítica mais pesada. Ela lembra que:

Os jagunços que já foram caracterizados como os titãs, que transformam o espaço dimensional natural em zonas de fontes de vida e de proteção, aparecem, nesse momento, como simples defensores de um lar construído que abrigava os excluídos da sociedade brasileira. (SOUSA, 2008, p. 36I).

Aqui, a crítica que não adquire tons de autocrítica - pois Euclides continuava sendo um republicano mesmo após o massacre - recai, todavia, sobre o lado "civilizado" e a falta de critérios racionais que atuariam por evitar o genocídio em detrimento do conhecimento das populações sertanejas (SOUSA, 2008). Os "tabaréus" foram alcunhados por ele antes, em um artigo de I897 para O Estado de S. Paulo chamado “Nossa Vendéia”. A Vendéia, local da fracassada e valente contrarrevolução francesa entre cristãos e republicanos, inspirava Euclides a acreditar que Canudos seria a versão brasileira da tentativa de uma volta monárquica. Assim, os "tabaréus", ou seja, os ingênuos (também chamados de "fanáticos" pelo autor), corriam o risco de colocar a evolução brasileira à prova.

Entre jagunços e tabaréus emerge a brasilidade. A ambiguidade de Euclides para tratar o sertanejo só é produzida pelo conhecimento empírico da realidade do sertão, descrita em detalhes nos capítulos iniciais da obra. O romantismo euclidiano dá lugar a uma descrição mais detalhada e submersa no universo experienciado e respostas menos políticas sobre o conflito. No lugar delas, parece surgir um tipo de distinção racial, como se a determinação biológica fosse o fator decisivo para o iminente conflito. O sertanejo não é apenas o não civilizado, mas uma sub-raça limitada pela própria mobilidade geográfica. Uma guerra inevitável pelo encontro decorrente entre a mestiçagem do homem litorâneo (mestiçagem entre o europeu e o negro) e do sertanejo (mestiçagem entre o bandeirante paulista e o indígena).

É evidente que aí aparece novamente a relação pensada por Taine, especialmente a do homem e o meio. Dizendo que "o sertanejo é, antes de tudo, um forte" (CUNHA, 20I2, p. 93), o escritor assemelha o meio ao sujeito vivente, com sua aridez constitutiva, porém conferindo ao "nativo" a força de peregrinar em busca de uma salvação, como uma "hégira sertaneja", comparando à migração de Maomé de Meca a Medina no século VII.

O sertão não é só um meio onde o homem sertanejo vive. Starling (2019) afirma que 
a palavra carrega ambiguidade - entre o potencial de liberdade e risco da barbárie - e uma solidão em meio à agressividade do entorno. O sertão não é só uma geografia, mas uma realidade política caracterizada pela inexistência de limites, precária de direitos e leis, constituída de um vazio. O sertão explica o Brasil, pois vai além do seu território geográfico e revela a marca do esquecimento de um país sobre si mesmo.

\section{MARCAÇÕES DE CONTEÚdO: O ESTRANGEIRO, O ÊXODO E O MIGRAR}

A construção dessa narrativa pode ser limitada ao uso, pelo autor, de algumas palavras que remetem ao universo do estrangeirismo e das migrações. Como um texto literário e também jornalístico, é possível afirmar que a obra de Euclides da Cunha seja categorizada como livro-reportagem, tal como Martins (20I0) considera. Para Edvaldo Lima (2008), o gênero distingue-se pelo conteúdo, tratamento e função, correspondendo, respectivamente, ao real, à linguagem jornalística e à função de informar e orientar de forma extensiva (buscando causas e efeitos, reconstruindo a história, investigando a denúncia etc.).

O guiamento da linguagem euclidiana situa-se entre a projeção jornalística de informar ao Sul o que se passava no Norte brasileiro (na época, a distinção geopolítica Nordeste ainda não existia) e uma linguagem literária que marca o romantismo na descrição detalhada do sertão e do sertanejo. Todavia, outro fator aparece de forma importante, como já citado na introdução: o componente científico, que perpassa a descrição territorial e a incorporação do povo e do contexto à obra, à luz dos pressupostos positivistas.

Algumas expressões que unem os estudos migratórios aparecem na obra de forma a dar a tonalidade de sentido ao livro. Nessa mescla proposta como livro-reportagem, entre jornalismo, literatura e ciência, mapeei expressões como "estrangeiro", "migrações" e "êxodo" (aproximadamente 25 recorrências) e seus momentos no livro para serem brevemente analisadas.

As expressões ligadas ao verbo "migrar", assim como a palavra "êxodo", na maioria dos casos aparecem como a condição existencial ligada à sobrevivência. Vinculada à ideia do retirante, a migração/êxodo, num primeiro momento, é fruto da seca que abate o sertão que, por ser ambiental, é temporária e sazonal.

Na plenitude das secas são positivamente o deserto. Mas quando estas não se prolongam ao ponto de originarem penosíssimos êxodos, o homem luta como as árvores, com as reservas armazenadas nos dias de abastança e, neste combate feroz, anônimo, terrivelmente obscuro, afogado na solidão das chapadas, a natureza não o abandona de todo. (CUNHA, 20I2, p. 49 - destaque meu).

Passa certo dia, a sua porta, a primeira turma de "retirantes" [...]. É o sertão que se esvazia. [...] e lá se vai ele no êxodo penosíssimo para a costa, para as serras distantes, para quaisquer lugares onde o não mate o elemento primordial da vida [...]

Passam-se meses. Acaba-se o flagelo. Ei-lo de volta. Vence-o saudade do sertão. Remigra. E torna feliz, revigorado, cantando [...]. (CUNHA, 20I2, p. IIo - destaques meus).

A relação dessas expressões ainda demarca o sentido de deslocamento no momento 
em que Euclides da Cunha descreve a fauna. Se o homem caminha pelo sertão, os animais também seguem o movimento por uma sobrevivência: "Despovoam-se aquelas grandes solidões alagadas, morrem os peixes nos rios, enregelados; morrem as aves nas matas silenciosas, ou emigram; esvaziam-se os ninhos" (CUNHA, 20I2, p. 68 - destaque meu).

A migração também é tratada pela imigração, ou seja, pela chegada dos europeus ao Brasil. Durante o livro, Euclides oscila na sua colocação frente a eles: ora os observa como civilização desejada, ora como os verdadeiros estrangeiros na sua interpretação nacionalista da nação. A elevação do tipo imigrante pode ser percebida logo início do texto, nas "Notas preliminares", mas a alusão aos benefícios e problematizações é recorrente a alguém de resguardo nacional.

Intentamos esboçar, palidamente embora, ante o olhar de futuros historiadores, os traços atuais mais expressivos das sub-raças sertanejas do Brasil. E fazêmo-lo porque a sua instabilidade de complexos de fatores múltiplos e diversamente combinados, aliada às vicissitudes históricas e deplorável situação mental em que jazem, as tornam talvez efêmeras, destinadas a próximo desaparecimento ante as exigências crescentes da civilização e a concorrência material intensiva das correntes migratórias que começam a invadir profundamente a nossa terra. (CUNHA, 20I2, p. I - destaque meu).

O homem sentia-se forte. Deslocado apenas o teatro dos grandes cometimentos, podia volver para o sertão impérvio a mesma audácia que o precipitara nos périplos africanos. Além disto - frisemos este ponto escandalizando embora os nossos minúsculos historiógrafos - a disposição orográfica libertava-o da preocupação de defender o litoral, onde aproava a cobiça do estrangeiro. (CUNHA, 20I2, p. 7I - destaque meu).

Ele lembra ainda que, para o português, "O Brasil era a terra do exílio" (CUNHA, 20I2, p. 74 - destaque meu), sobretudo nas porções litorâneas, já sem o ímpeto dos colonizadores do início do Brasil. A presença do imigrante europeu influenciava na mestiçagem que diferenciava o brasileiro litorâneo do sertanejo, argumentando que as migrações estimulam a mestiçagem, que macula a nacionalidade. Ao mesmo tempo, a nacionalidade euclidiana novamente se coloca em oposição à sua ideologia. Na segunda citação, o estrangeiro já não é o imigrante europeu, mas o sertanejo distanciado por séculos da civilização:

E não nos demasiamos em arrojada hipótese admitindo que este tipo extraordinário do paulista, surgindo e decaindo logo no Sul, numa degeneração completa ao ponto de declinar no próprio território que lhe deu o nome, ali renascesse e, sem os perigos das migrações e do cruzamento, se conservasse [...] (CUNHA, 20I2, p. 82 - destaque meu).

Iludidos por uma civilização de empréstimo; respigando, em faina cega de copistas, tudo o que de melhor existe nos códigos orgânicos de outras nações, tornamos, revolucionariamente, fugindo ao transigir mais ligeiro com as exigências da nossa própria nacionalidade, mais fundo o contraste entre o nosso modo de viver e o daqueles rudes patrícios mais estrangeiros nesta terra do que os imigrantes da Europa. (CUNHA, 20I2, p. I58 - destaques meus). 
Por fim, pois as demais citações que poderiam ser feitas apenas coadunam o que já foi exposto durante este artigo, vale ressaltar as exposições do que seria o êxodo, ao fim da narrativa.

Os foragidos, já agora salvos, suportavam os últimos transes do êxodo penosíssimo requintando nas tropelias, ampliando o círculo de ruínas da guerra e iam-se de abalada para o litoral - ao mesmo tempo miserandos e maus, inspirando a piedade e o ódio rudemente vitimados, brutalmente vitimando. (CUNHA, 20I2, p. 356 - destaque meu).

Euclides guarda para a trama final a ação do deslocamento como luta pela sobrevivência, não mais pelas adversas condições climáticas, porém pela adversa situação na qual o homem se colocou. A da guerra, do genocídio, componentes que delimitam a amplitude civilizacional das forças nacionais e as próprias convicções de Euclides. Ali, o livro-reportagem já não cumpriria seu objetivo inicial e se colocaria como um marco na literatura brasileira, sem antes ter sido censurado pela intelligentsia da época.

\section{A imprensa de elite E O SEU lUgar de FALA}

Foco aqui na expressão jornalística d'Os sertões, abrindo um vértice para a relação estrutural do texto e seu veículo (a imprensa), também uma enunciação. Adepto dessa crítica estrutural e fundamentado pelo marxismo, foi Nelson Werneck Sodré que, em História da imprensa no Brasil, publicado pela primeira vez em I966, traçou uma radiografia detalhada da imprensa brasileira, iniciando no período colonial (cujas atividades começaram tardiamente, apenas 300 anos após a chegada dos portugueses) e indo até meados do século XX, mais propriamente nos anos I960, quando já diagnostica aquilo que chamaria de uma "crise da imprensa", justamente pelas condições materiais que caracterizam a sociedade capitalista. Em síntese, e como um bom marxista, Werneck Sodré atrela a decadência do jornalismo à ascensão da "grande imprensa", menos artesanal e política (panfletária, militante) e mais empresarial (RIBEIRO, 20I5).

Outra etapa de análise desse historiador se encontra antes da ascensão da grande imprensa. No momento chamado de "A imprensa do Império", datado entre a segunda metade do século XIX e o início do século XX, Werneck Sodré (I999) traça a gênese da grande imprensa, motivada pelas tecnologias de impressão que aumentam a rotatividade e criam a empresa jornalística, aliada ao desenvolvimento da indústria cafeeira, a abolição da escravidão (I888) e a Proclamação da República (I889). Nesse universo estão Euclides da Cunha, a Guerra de Canudos e O Estado de S. Paulo, como veículo de imprensa da futura maior cidade do país, transformada pela mão de obra migrante e pelo crescente capitalismo industrial.

A redação de Os sertões está, então, submersa nessas novas práticas jornalísticas que, segundo Ana Paula Ribeiro (20I5), adotavam padrões estrangeiros, trocando os folhetins e as caricaturas pelas revistas ilustradas, de críticas e de costumes. Se o livro está justamente na troca de séculos que, durante o texto, resumi como um movimento que vai do romantismo para um objetivismo positivista, Sousa (2008) afirma que a escrita euclidiana influenciou a imprensa posterior a Canudos. 
Sua narrativa descritiva traz para o centro as classes subalternas e toda a função estética desempenhada pelo autor ao mesmo tempo que sua escrita trilha um caminho repleto de opiniões, persuadindo leitores a respeito do que ela chama de uma "conspiração monárquica por parte dos conselheiristas" (SOUSA, 2008, p. 363).

Embora Sodré (1999) distinga a imprensa panfletária da grande imprensa, esta, como sabemos, não está imune à parcialidade, embora se caracterize pela defesa da isenção como valor empresarial. Não apenas a imprensa liberal como empreendimento capitalista, mas todo o mote ideológico do positivismo assim se produz. Na bandeira brasileira está escrito seu lema, "ordem e progresso", naturalizado como objeto de verdade. É pela ordem que se chega ao progresso, dirá um cidadão nas ruas. Defendendo a ideia, não pode responder, contudo, a qual ordem e a qual progresso o lema de refere, pois os conceitos, totalizados na cultura, são assimilados por ela como objetos estáticos e puros.

A contestação da hegemonia cultural, mantida no estandarte da neutralidade, é contraposta pelos diferentes discursos que podem povoar o conteúdo midiático. Se Sousa (2008) afirma que, em Os sertões, a classe subalterna dos sertanejos aparece como protagonista, a narração ainda é oriunda do militar vivente no eixo Rio-São Paulo. A ausência da concepção do lugar de fala é incipiente na imprensa, em geral. Djamila Ribeiro (20I7) lembra que esse "lugar" não diz respeito à exclusividade da fala, mas à compreensão de que pontos de vista atuam sobre determinados indivíduos de formas particulares. Esse ponto de vista atuou sobre Euclides, cujo estatuto de testemunha do acontecimento, ao lhe dar acesso direto a ele, também o viabiliza ao direito à fala e à comunicação (SODRÉ, 2009), modificando, todavia, sua matriz cultural.

A inversão de rumo ao fim da obra é clara quando Euclides se vê perguntando: onde estava, de fato, o incivilizado? Se sua dúvida estava na lógica da barbárie, podemos questionar a civilidade pela lente dos relegados e dos que relegam. Se o sertão é a imagem do deserto, como admitiu, não é só o componente objetivo do terreno e do clima que confronta tal comparação. É a dinâmica subjetiva, do abandono, mas também do isolamento ao qual a história não iria com seu Iluminismo civilizatório. Pois é justamente uma outra civilização que ali se impõe, negando a outra que a renega a não ter nome, nem direito à personalidade legal de cidadãos, como afirma Starling (2019).

E não seria essa também a dinâmica de muitos migrantes, relegados a um presente que elimina seu passado, como afirma Schütz (20I0) na análise espaçotemporal da relação estrangeiro-nativo? A principal contribuição de Euclides da Cunha ao tema das migrações não está na geografia, mas nesse aspecto subjetivo da estrangeiridade. É essa a camada mais profunda não facilmente vista na superfície de sua obra. Uma distância infinitamente maior separava os republicanos daqueles sertanejos, estrangeiros um para o outro. Distância diminuída para os que visitaram Canudos. Para Euclides, mas também para os soldados combatentes, que, ao se verem desamparados pelo poder que defendiam, deram o nome aos seus casebres no Rio de Janeiro de "favelas". A planta do sertão unia-os na situação de desamparo no Morro da Providência. Seriam eles os novos estrangeiros, os novos indesejados no Brasil do século XX, mais urbano e de, igual forma, segregado. 


\section{CONCLUSÃO: HÁ SEMPRE UM OUTRO OS SERTÕES PARA DESVENDAR}

Definitivamente, Os sertões é uma das principais obras explicadoras do Brasil. Publicada logo nos primeiros anos do século XX, o texto, como todos os outros clássicos, não dá conta de explicar a totalidade de uma nação mutifacetada, mas traz diagnósticos particulares da nossa vida social. Dois deles tentei destacar ao longo do artigo.

Um, no primeiro plano e transversal a todo o texto, refere-se à estrangeiridade dos sertanejos frente aos homens do centro do Brasil (eixo Rio-São Paulo). De forma proposital, terminei falando dos combatentes de Canudos, que, ao voltarem para sua cidade e aguardando uma promessa não cumprida do governo federal, ocuparam o Morro da Providência e formaram a primeira favela. No Brasil, sempre há estrangeiros, que não precisam necessariamente ser imigrantes ou refugiados. É da ordem da cor, do bairro, da expressão sexual, da religião e de tantas outras formas que se opõem ao ideal civilizacional construído pela geração de Euclides da Cunha, que nos construímos como nação.

O segundo ponto que busquei diagnosticar, ainda que se forma reduzida, foi a ação da imprensa na reelaboração da ordem "civilizacional”. A "grande imprensa", à qual se refere Sodré (I999), substitui a militância e a imprensa do baixo clero (de imigrantes ligados ao operariado, por exemplo, gênese do jornalismo sindical) por uma forma midiática profissionalizada, empresarial e lucrativa. Sob a ética e o ideal da neutralidade, o jornalismo brasileiro manteve-se no poder contribuindo em processos eleitorais, como na ascensão ao poder vista no golpe militar de I964 e na eleição de Fernando Collor de Melo, em I989, e até nas derrotas eleitorais convertidas em vitoriosas narrativas empresariais, sob o guarda-chuva do livre-mercado e da totalização do discurso econômico, como o país acostumou-se a ver nos últimos 50 anos.

Essa união entre ideologia e poder midiático por vezes conferiu descrédito às camadas populares em detrimento de valores civilizacionais hegemônicos construídos pela revolução burguesa europeia. Cabe ressaltar que, embora certa elite intelectual e financeira brasileira adote essa estratégia, grande parte do povo, não, que esperava um momento para marcar seus sentimentos e vozes, o que parece ter se produzido no desenvolvimento de tecnologias planificadoras (dentro de certos limites) dessas vozes. Nesse sentido, a utopia que marcou a narrativa do século XX permaneceu entre a esquerda brasileira, inclusive nos estudos de comunicação e jornalismo que admitiam um horizonte de esperança com a ascensão da democratização das mídias pela imprensa popular e comunitária. Mas outro grupo, mais quieto e recolhido nesse período, também manifestava a mesma esperança, apenas em parte sintonizado ao discurso hegemônico liberal.

Eram grupos alinhados a perspectivas conservadoras, que admitem na economia a frente do livre-mercado, mas recusam a ideologia liberal na formação sociocultural. Na Europa aparecem na recusa à abertura de fronteiras e, na América Latina, na reafirmação moralista da religião única e do ideal de estrutura familiar, admitida somente entre o homem e a mulher. Ambas as expressões são ligadas aos essencialismos que configurariam a tradição nacional, expressões, por sua vez, de uma colonialidade que insiste em permanecer.

E aí retomo Euclides da Cunha. Não à toa, figuras expressivas do conservadorismo brasileiro utilizam Os sertões como explicação do perigo do avanço liberal contra as 
tradições (no livro exploradas pelo monarquismo) provenientes da nação e defendidas pelo povo. Em um momento de proliferação da opinião, aqueles que se mantiveram fora do discurso científico, agora, não mais um cientificismo redutor, sentem-se possibilitados a dizer o que pensam e sentem, e o dialogismo pensado por intelectuais da democratização do saber e das mídias dá lugar a estratégias de sedução, não mais sob o modelo típico burguês, mas sob uma forma mais próxima ao povo: um populismo discursivo que se mistura a um messianismo e uma crença absoluta na representação.

Esta é a ambiguidade que era necessário estabelecer ao se demarcar a importância da obra, ao mesmo tempo que a reelaboração na opinião pública de um conservadorismo contemporâneo chega ao povo - movimento desejado pelos socialistas a si mesmos sem, de fato, descortinar a hegemonia e a colonialidade em nós presentes.

\section{SOBRE O AUTOR}

OTÁVIO ÁVILA é doutorando em Comunicação e Cultura na Universidade Federal do Rio de Janeiro (UFRJ) e integrante do grupo de pesquisa Diaspotics: Migrações Transnacionais e Comunicação Intercultural (https://diaspotics.org/). ota_cez@hotmail.com https://orcid.org/oooo-0002-6495-6226

\section{REFERÊNCIAS}

BAUMAN, Z. O mal-estar na pós-modernidade. Rio de Janeiro: Jorge Zahar, I998.

BHABHA, H. K. O local da cultura. 2. ed. Belo Horizonte: Editora UFMG, 2013

BHABHA, H. K. The other question: difference, discrimination and the discourse of colonialism. In: BARKER, F. et al. (ed.). Literature, politics and theory. Papers from the Essex Conference I976-I984. London and New York: Routledge, 2003, p. I48-I72. (The New Accent Series).

BRANDÃO, C. Território e desenvolvimento: as múltiplas escalas entre o local e o global. 2. ed. Campinas: Editora Unicamp, 2012.

CHIARELLI, S. Que Brasil existe? Estrangeiros na literatura brasileira. Intelligere, v. 2, n. 2, 20I6. Disponível em: http://www.revistas.usp.br/revistaintelligere/article/view/II7632. Acesso em: I8 jun. 2020. CUNHA, E. Os sertões: Campanha de Canudos (Versão Digital). São Paulo: Moderna, 2012.

DELEUZE, G. Lógica do sentido. São Paulo: Perspectiva, I974.

DYER, R. Gays and film. Londres: British Film Institute, I977.

FAVRET-SAADA, J. Ser afetado. Cadernos de Campo, v. I3, n. I3, 2005, pp. I55-I6I. Disponível em: http://www. revistas.usp.br/cadernosdecampo/article/view/50263. Acesso em: I8 jun. 2020.

HALL, S. Cultura e representação. Rio de Janeiro: Editora PUC-Rio/Apicuri, 2016.

KARAKAYALI, N. The uses of the stranger: circulation, arbitration, secrecy, and dirt. Sociological 
Theory, v. 24, n. 4, 2006, pp. 3I3-330. Disponível em: https://journals.sagepub.com/doi/Io.IIII/j. I467-9558.2006.00293.x. Acesso em: I8 jun. 2020.

LIMA, E. P. Páginas ampliadas: o livro-reportagem como extensão do jornalismo e da literatura. $4^{\mathrm{a}}$ edição. Barueri: Manole, 2008.

MARTINS, R. R. Livro-reportagem: entre o jornalismo e a literatura. In: CONGRESSO BRASILEIRO DE CIÊNCIAS DA COMUNICAÇÃO, 33., Caxias do Sul, RS, Brasil. Sociedade Brasileira de Estudos Interdisciplinares da Comunicação - Intercom. Anais... 20Io. Disponível em: http://www.intercom.org.br/ papers/nacionais/20Io/resumos/R5-2765-I.pdf. Acesso em: I8 jun. 2020.

OLIVEIRA, R. Euclides da Cunha, Os sertões e a invenção de um Brasil profundo. Revista Brasileira de História, v. 22, n. 44, 2002, p. 5II-537. Disponível em: https://www.scielo.br/scielo.php?pi$\mathrm{d}=$ SoI02-0I8820020002000I2\&script=sci_abstract\&tlng=pt. Acesso em: I8 jun. 2020.

PRADO JÚNIOR, C. Formação do Brasil contemporâneo: colônia. São Paulo: Companhia das Letras, $20 I I$.

RIBEIRO, A. P. G. Nelson Werneck Sodré e a história da imprensa no Brasil. Intercom: Revista Brasileira de Ciências da Comunicação, v. 38, n. 2, jul.-dez 20I5, p. 275-288. Disponível em: https://www.scielo. br/pdf/interc/v38n2/I809-5844-interc-38-02-0275.pdf. Acesso em: I8 jun. 2020.

RIBEIRO, D. O que é lugar de fala?. Belo Horizonte: Letramento, 2017.

SAID, E. W. Orientalismo: Oriente como invenção do Ocidente. São Paulo: Companhia das Letras, I978.

SAYAD, A. A imigração ou os paradoxos da alteridade. São Paulo: Edusp, I998.

SCHRÖDER, U. Comunicação intercultural: uma desconstrução e reconstrução de um termo inflacionário. Cadernos de Linguagem e Sociedade, v. 9, n. I, 2008, p. 38-49. Disponível em: https://periodicos.unb. br/index.php/les/article/view/9259. Acesso em: I8 jun. 2020.

SCHÜTZ, A. O estrangeiro: um ensaio em psicologia social. Revista Espaço Acadêmico, v. Io, n. Iᄑ3, 20Io, p. II7-I29. Tradução: Márcio Duarte e Michael Hanke. Disponível em: http://www.periodicos.uem.br/ ojs/index.php/EspacoAcademico/article/view/II345. Acesso em: I8 jun. 2020.

SEVCENKO, N. Literatura como missão. São Paulo: Brasiliense, 1989.

SIMMEL, G. The stranger. New York: Free Press, I950.

SODRÉ, M. A narração do fato: notas para uma teoria do acontecimento. Petrópolis: Vozes, 2009.

SODRÉ, M. A ciência do comum: notas para o método comunicacional. Petrópolis: Vozes, 2014.

SODRÉ, N. W. História da imprensa no Brasil. 4. ed. Rio de Janeiro: Mauad, I999.

SOUSA, L. Euclides da Cunha e o bicentenário da imprensa. Revista da Anpoll, v. I, n. 25, 2008, p. 355-370.

Disponível em: https://anpoll.emnuvens.com.br/revista/article/view/75. Acesso em: I8 jun. 2020.

SOUZA, J. A elite do atraso. Rio de Janeiro: Estação Brasil, 2019.

STARLING, H. M. A palavra "sertão" e uma história pouco edificante sobre o Brasil. Pernambuco - Jornal Literário da Companhia Editora de Pernambuco [online]. II março 20I9. Disponível em: http://www. suplementopernambuco.com.br/artigos/2243-a-palavra-sert\%C3\%A3o-e-uma-hist\%C3\%B3ria-pouco-edificante-sobre-o-brasil.html. Acesso em: 2 jun. 2019. 